\title{
Long-term vegetation monitoring in Great Britain - the Countryside Survey 1978-2007 and beyond
}

\author{
Claire M. Wood ${ }^{1}$, Simon M. Smart ${ }^{1}$, Robert G. H. Bunce ${ }^{2}$, Lisa R. Norton ${ }^{1}$, Lindsay C. Maskell ${ }^{1}$, \\ David C. Howard ${ }^{1}$, W. Andrew Scott ${ }^{1}$, and Peter A. Henrys ${ }^{1}$ \\ ${ }^{1}$ Centre for Ecology and Hydrology, Lancaster Environment Centre, Bailrigg, Lancaster, LA1 4AP, UK \\ ${ }^{2}$ Estonian University of Life Sciences, Kreuzwaldi 5, 51014 Tartu, Estonia
}

Correspondence to: C. M. Wood (clamw@ceh.ac.uk)

Received: 24 February 2017 - Discussion started: 6 March 2017

Revised: 13 June 2017 - Accepted: 15 June 2017 - Published: 20 July 2017

\begin{abstract}
The Countryside Survey (CS) of Great Britain provides a globally unique series of datasets, consisting of an extensive set of repeated ecological measurements at a national scale, covering a time span of 29 years. CS was first undertaken in 1978 to monitor ecological and land use change in Britain using standardised procedures for recording ecological data from representative $1 \mathrm{~km}$ squares throughout the country. The same sites, with some additional squares, were used for subsequent surveys of vegetation undertaken in 1990, 1998 and 2007, with the intention of future surveys. Other data records include soils, freshwater habitats and invertebrates, and land cover and landscape feature diversity and extents. These data have been recorded in the same locations on analogous dates. However, the present paper describes only the details of the vegetation surveys.

The survey design is a series of gridded, stratified, randomly selected $1 \mathrm{~km}$ squares taken as representative of classes derived from a statistical environmental classification of Britain. In the 1978 survey, 256 one-kilometre sample squares were recorded, increasing to 506 in 1990, 569 in 1998 and 591 in 2007. Initially each square contained up to 11 dispersed vegetation plots but additional plots were later placed in different features so that eventually up to 36 additional sampling plots were recorded, all of which can be relocated where possible (unless the plot has been lost, for example as a consequence of building work), providing a total of 16992 plots by 2007 . Plots are estimated to have a precise relocation accuracy of $85 \%$. A range of plots located in different land cover types and landscape features (for example, field boundaries) are included.

Although a range of analyses have already been carried out, with changes in the vegetation being related to a range of drivers at local and national scales, there is major potential for further analyses, for example in relation to climate change. Although the precise locations of the plots are restricted, largely for reasons of landowner confidentiality, sample sites are intended to be representative of larger areas, and many potential opportunities for further analyses remain.

Data from each of the survey years $(1978,1990,1998,2007)$ are available via the following DOIs: Countryside Survey 1978 vegetation plot data (https://doi.org/10.5285/67bbfabb-d981-4ced-b7e7225205de9c96), Countryside Survey 1990 vegetation plot data (https://doi.org/10.5285/26e79792-5ffc-41169ac7-72193dd7f191), Countryside Survey 1998 vegetation plot data (https://doi.org/10.5285/07896bb2-7078468c-b56d-fb8b41d47065), Countryside Survey 2007 vegetation plot data (https://doi.org/10.5285/57f979158ff1-473b-8c77-2564cbd747bc).
\end{abstract}




\section{Introduction}

The Countryside Survey (CS) of Great Britain was initiated in the late 1970s to monitor ecological and land cover change using quantitative and repeatable methods. The history of the development of the methodology is given by Sheail and Bunce (2003). The survey is based on $1 \mathrm{~km}$ squares as a convenient sized unit, which had previously been tested in Cumbria (Bunce and Smith, 1978) and Shetland (Wood and Bunce, 2016) in the years preceding the first survey in 1978. The survey design is based on a series of dispersed, stratified, randomly selected $1 \mathrm{~km}$ squares from across Britain, which numbered 256 in 1978, 506 in 1990, 569 in 1998 and 591 in 2007. The stratification used was the statistical environmental classification of $1 \mathrm{~km}$ squares in Great Britain as described in Bunce et al. (1996b, c), and summarised in Sect. 2.2.

In the first survey, data were recorded from up to 11 vegetation plots of four different types, distributed through each of the squares (which form the main subject of the present paper), along with soil samples and land cover maps using standard classes which were later converted into standard habitat categories (Wood et al., 2012). Subsequent surveys including the vegetation component were undertaken in 1990, 1998 and most recently, 2007 (with an additional land use survey in 1984). During this period, additional vegetation plots have been placed in different land cover types and landscape features for policy objectives, eventually giving up to 36 more plots per square. Varying numbers of each vegetation plot type were initially placed in locations across each survey square according to rules outlined in Sect. 3. In subsequent surveys, these plots are repeated in these same fixed positions, except those such as on field margins, which are based on rules applied in the field. Details of the types of plot employed are described below, with an average of 29 plots being completed in each sample square. In addition to the vegetation plots described here, data are also recorded from linear features such as hedgerows, landscape elements such as veteran trees, areal broad habitats (Jackson, 2000) and related key species, soils and aquatic invertebrates (see Carey et al., 2008).

The survey as a whole provides a wealth of globally unique ecological data, consisting of an extensive range of measurements at a national scale, covering a time span of 29 years. From an international perspective, CS was a pioneer in surveys of its type. Although environmental surveys such as forest monitoring programmes were nothing new (e.g. United States Forest Service, http://www.fia.fs.fed.us/; Forest Survey of India, http://fsi.nic.in/), the integrated, systematic national monitoring of vegetation species, soils and landscape features across all land uses provided by CS was a novel concept, preceding programmes in many other countries particularly in Europe (e.g. Dramstad et al., 2002; Hintermann et al., 2002; Ståhl et al., 2011) and beyond (e.g. Burton et al., 2014).

\section{Survey design: background, stratification and site selection}

\subsection{Background}

As a result of the earlier work carried out in the 1970s on a regional scale (Wood and Bunce, 2016; Bunce and Smith, 1978), a sample unit of $1 \mathrm{~km}$ square was found to be an appropriate size for CS. It also forms the basic unit of the stratification framework described below. A $1 \mathrm{~km}$ square is small enough to survey in a reasonable period of time (1 week or less) and yet large enough to contain sufficient environmental features to allow differentiation between squares. Kilometre squares are used as a framework by the British national mapping agency, the Ordnance Survey, thus providing useful basemaps to aid surveyor navigation. A sampling unit of $1 \mathrm{~km}$ square is also widely used in other European projects (for example in Spain, Ortega et al., 2013), although in countries with small-scale landscapes, for example Northern Ireland, $0.25 \mathrm{~km}$ square has been adopted (Cooper et al., 2009).

\subsection{Stratification}

With over 240000 of $1 \mathrm{~km}$ squares in Great Britain, a sampling approach was essential and a statistical environmental classification was constructed, from which the stratified, random samples of $1 \mathrm{~km}$ squares were taken. Due to the limitations of computing power and lack of readily available data at the time, the classification initially only covered a subset of 1212 one-kilometre squares, rather than the whole of Britain, based on a $15 \times 15 \mathrm{~km}$ grid drawn from the National Grid defined by Britain's national mapping agency, the Ordnance Survey.

Altitude, climate, geology, human geography and location variables from each $1 \mathrm{~km}$ square were recorded manually for each $1 \mathrm{~km}$ square. Because the data were a mixture of variables (for example, altitude) and attributes (for example, geology) the variables were converted into four classes so that the database was suitable for analysis by indicator species analysis (ISA, now TWINSPAN (Hill and Šmilauer, 2005) and stopped at 32 classes. It is recognised that nowadays, with automated data capture, variables can be recorded for millions of $1 \mathrm{~km}$ squares, and recent environmental classifications (for example Metzger et al., 2008; Villoslada et al., 2016) have used principal component analysis and clustering. Jones and Bunce (1985) compared classifications of European climate using both methods and concluded that the results were comparable. Bunce et al. (2002) compared classifications for similar regions using different databases and analytical techniques and showed that the basic patterns were sufficiently close that policy makers would be able to have confidence in the results. The many multivariate techniques which are now available will give slightly different boundaries to classes but the core structure will always be identified. Finally, any inefficiencies in stratifications will be re- 
flected in higher standard errors for the observed independent variables. The independent tests in papers such as Metzger et al. (2008) and Villoslada et al. (2016) are all highly significant and any improvements are likely to be marginal.

The resulting classes were described on the basis of average values of the environmental characteristics of the initial database, for example, altitude and rainfall (Bunce et al., 1996a, c).

A primary objective of the methodology is to reduce variation, as the classification divides the population into discrete strata which are then used to derive samples from which ecological parameters such as vegetation can be recorded. As a statistically robust method is used (i.e. ISA), it is possible to extrapolate the results from the sample sites into land class means, which can then be combined to describe an entire population (for example England, Scotland, Wales or Britain). The principles and development of this procedure are described by (Sheail and Bunce, 2003).

By 1990, all $1 \mathrm{~km}$ squares in Great Britain were classified into the same set of strata, which was not considered possible at the start of the 1970s. Known as the "Institute of Terrestrial Ecology (ITE) Land Classification of Great Britain" (Bunce et al., 1990, 1996a, b), it has developed over the 30year period (Sheail and Bunce, 2003). The most recent modifications largely concern the incorporation of the requirement for country level reporting, separating Scotland (in 1998) and Wales (in 2007). The basic stratification still underpins the CS and the latest development of the original Land Classification consists of 45 classes (or strata), and is illustrated in Fig. 1, along with a map of the distribution of sampling locations (Fig. 2).

\subsection{Site selection}

Having constructed this initial stratification, the number of samples to be surveyed in the first (1978) survey was considered. Ideally, this number would depend on the size of the stratum (i.e. how many $1 \mathrm{~km}$ squares of the class occurred in Great Britain) and on the ecological variability within the stratum. Preliminary work had suggested that for ecological surveys of this type, at least eight samples per stratum were necessary in order to be representative of that stratum. Eight $1 \mathrm{~km}$ squares were therefore selected at random from each of the classes from the grid of classified squares. Thus the final sample for the first Great Britain survey was a gridded, stratified, random sample of $256 \times 1 \mathrm{~km}$ squares. Surveying commenced in 1977 , although the majority of squares were surveyed in 1978 . Note that the location of the $1 \mathrm{~km}$ sample squares is not disclosed by agreement with land owners; the majority of the land in the sample squares is in private ownership. If the locations of the sites were made available, this would not only threaten future surveys but also prevent and future collaboration with the owners or their descendants. Furthermore, future land use decisions could be influenced and have an effect on the monitoring results. Thus

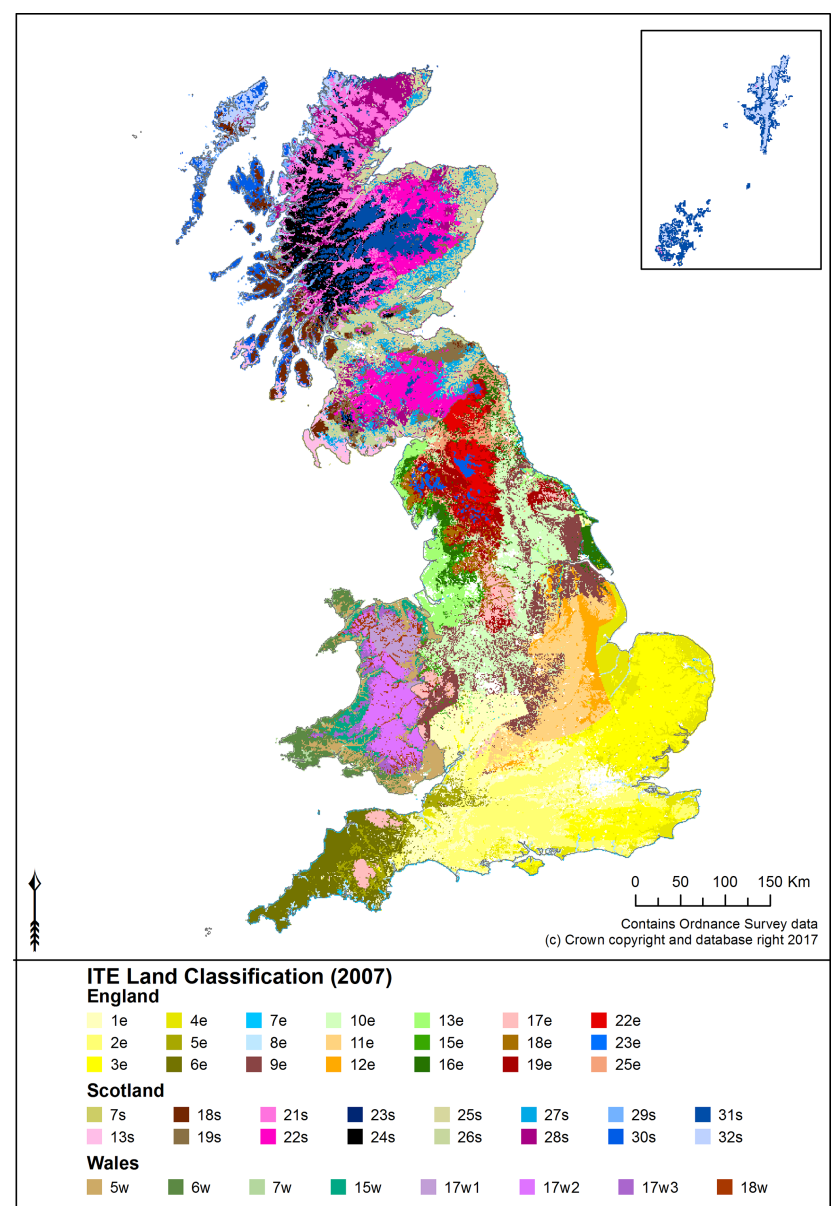

Figure 1. ITE Land Classification, 2007.

this policy ensures that the squares do not attract additional research or land management activity that could potentially undermine their status as an unbiased, representative sample of the British countryside. In spite of the restrictions placed on the site locations, the data may be used in a wide range of analyses on a national or regional level, as described more fully in Sect. 7 .

\section{Sampling sites and plots}

Initially, vegetation and soil data were recorded from five dispersed random ("X") plots in each $1 \mathrm{~km}$ square, which were located using a restricted randomisation procedure designed to reduce auto-correlation. Depending on the type of analyses in question, data users may wish to account for spatial auto-correlation, as in Baude et al (2016). However, in the majority of cases this is not an issue, as described by Betts et al. (2009), and as shown by in model checks in, for example, Henrys et al. (2015b). Vegetation was sampled from a further six plots placed along linear features (two hedgerow ("H") plots, two streamside ("S") plots, and two roadside ("R") plots). Plots have never been placed in built-up areas or be- 

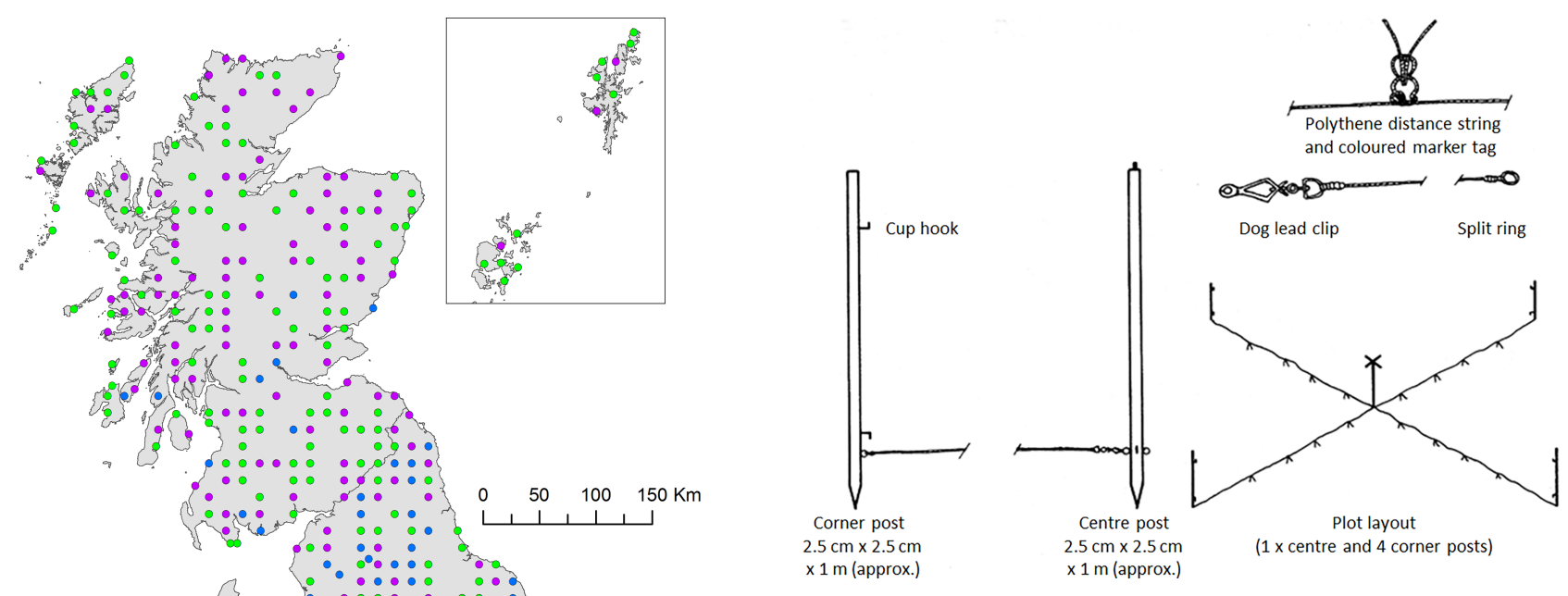

Figure 3. X plot construction.

\section{Data collected}

The vegetation survey involves recording plant species presence and abundance in different sizes and types of vegetation plot. In each vegetation plot, a complete list of all vascular plants and a selected range of readily identifiable bryophytes and macro-lichens is made (with the exception of D plots, which record woody species only). The field training course held before the surveys covered identification of difficult species, regular visits were made to survey teams by managers, and difficult specimens could be collected and sent to experts for identification. However, predetermined combinations of species may be recorded as aggregates reflecting known difficulties in their separation in the field (refer to Maskell et al., 2008; Barr, 1998). Cover estimates are made to the nearest $5 \%$ for all species reaching at least an estimated $5 \%$ cover. Presence is recorded if cover is less than $5 \%$. Canopy cover of overhanging trees and shrubs is also noted, even if individuals were not rooted within the plot. Additionally, general information about the plot is recorded to provide supporting information for analytical purposes as well as describing potential habitats such as glades and dead wood.

The total number of plots within squares varies depending on the landscape type and range of landscape features. Plots differ in size depending upon their type (Table 1). By 2007, the mean number of plots per square was 29 (min. 2, max. 47). The locations of all plots were mapped, together with measurements to local features, thus allowing them to be found again and re-recorded in the same place. Additional information ensuring the highest degree of accuracy when re-finding plots began to be recorded in the 1990 survey, as described in Sect. 4.2. The same plot locations have been repeated in all subsequent surveys (where appropriate), with additions.

\subsection{Plot types}

$X$ plots - large or main plots

The $\mathrm{X}$ plots are large nested plots designed to provide a random sample in proportion to the extent of the different vegetation types in each square and therefore in the wider countryside. X plots were pre-located before going into the field, with one plot being randomly placed into one of 5 equal sectors dividing the $1 \mathrm{~km}$ survey square. $\mathrm{X}$ plots typically sample the most common vegetation types. The $\mathrm{X}$ plot is $200 \mathrm{~m}^{2}$ $(14.14 \times 14.14 \mathrm{~m})$; the large size was adopted to obtain the maximum number of species within the plot. The methodol- 
Table 1. Summary of vegetation plot types, sizes and numbers.

\begin{tabular}{|c|c|c|c|c|c|}
\hline Code & Name & Other names & Where & Size & No. per square \\
\hline \multicolumn{6}{|c|}{ Areal plots } \\
\hline $\mathrm{X}^{1}$ & Large & $\begin{array}{l}\text { "Wally plot"; } \\
\text { main }\end{array}$ & Random points in open polygons & $200 \mathrm{~m}^{2}$ & 5 \\
\hline$Y^{2+4}$ & Small & $\begin{array}{l}\text { Targeted } \\
\text { habitat }\end{array}$ & $\begin{array}{l}\text { Uncommon vegetation types and in } 2007 \text {, } \\
\text { Priority habitats }\end{array}$ & $4 \mathrm{~m}^{2}$ & Up to 5 \\
\hline \multicolumn{6}{|c|}{ Linear plots } \\
\hline $\mathrm{B}^{2}$ & Boundary & & Adjacent to field boundaries and paired with X plots & $10 \times 1 \mathrm{~m}$ & 5 \\
\hline$A^{3}$ & Arable & & Arable field edges centred on each B plot & $100 \times 1 \mathrm{~m}$ & Up to 5 \\
\hline$M^{4+5}$ & Margin & & Field margins & $2 \times 2 \mathrm{~m}$ & Up to 15 \\
\hline $\mathrm{H}^{1}$ & Hedgerow & & Alongside hedgerows & $10 \times 1 \mathrm{~m}$ & 2 \\
\hline
\end{tabular}

${ }^{1}$ First recorded in $1978 ;{ }^{2}$ first recorded in $1990 ;{ }^{3}$ first recorded in $1998 ;{ }^{4}$ first recorded in $2007 ;{ }^{5}$ if there are five A plots in a square and wide margins.

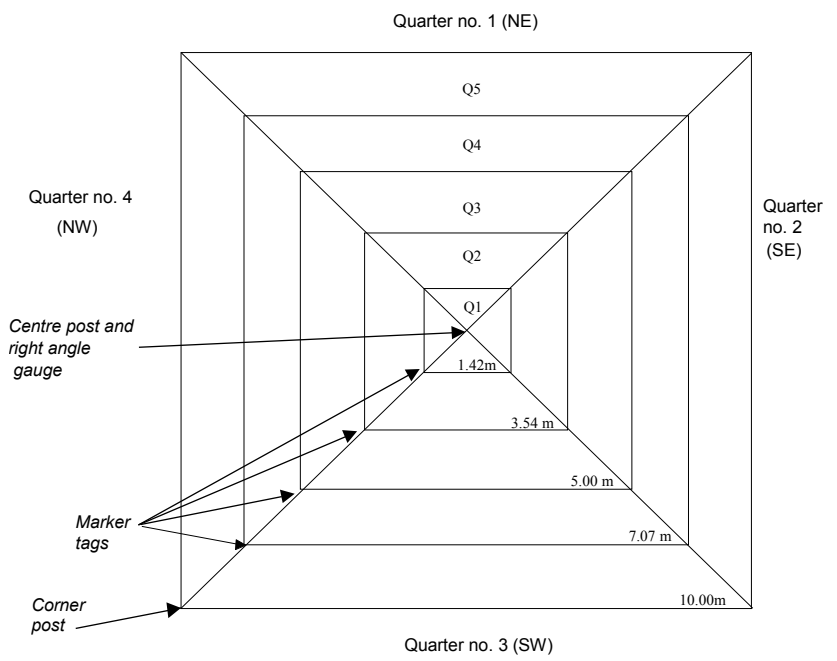

Distance string position from centre $-1 / 2$ diagonal:

$\mathrm{Q} 1=4 \mathrm{~m}^{2}$ quadrat $(2 \mathrm{~m} \times 2 \mathrm{~m})=1.42 \mathrm{~m}$ diagonal

$\mathrm{Q} 2=25 \mathrm{~m}^{2}(5.00 \times 5.00 \mathrm{~m})=3.54 \mathrm{~m}$

$\left.\mathrm{Q} 3=50 \mathrm{~m}^{2} 7.07 \times 7.07 \mathrm{~m}\right)=5.00 \mathrm{~m}$

$\mathrm{Q} 4=100 \mathrm{~m}^{2}(10.00 \times 10.00 \mathrm{~m})=7.07 \mathrm{~m}$

$\mathrm{Q} 5=200 \mathrm{~m}^{2}(14.14 \times 14.14 \mathrm{~m})=10.00 \mathrm{~m}$

Not to scale

Figure 4. Layout of vegetation X plot.

ogy was originally produced for woodlands as described by Bunce and Shaw (1973) and was also used and found appropriate for strategic ecological survey, as described by Bunce and Smith (1978). The design of the plot not only aids a systematic search of the vegetation present but is straightforward to set out in the field, and ensures a standard area of the plot is covered on every occasion, making a square plot more advantageous than a circular plot in this case. The plot is set up by using a centre post and four corner posts, with a set of four strings tagged with markers at specified distances. The tagged strings form the diagonals of the square (as shown in Fig. 3). The diagonals should be orientated carefully at right angles and the plot should be orientated with the strings on the north/south, east/west axes. The different nested plots shown in Fig. 4 are marked by different coloured strings on the appropriate position of the diagonal. The design is to ensure that the whole plot is observed consistently and systematically, as unstructured search routines are more likely to lead to species being overlooked, as described as far back as 1940, by Hope-Simpson (1940).

Within the plot shown in Fig. 4, the first nest of the plot $(2 \times 2 \mathrm{~m})$ is searched first. This procedure is then repeated for each nest of the quadrat, increasing the size each time and only recording additional species discovered in each larger nest (Fig. 4). In the final nest (the whole $200 \mathrm{~m}^{2}$ plot), the percentage cover (to the nearest $5 \%$ ) of each species is also estimated. Estimates of cover for litter, wood, rock and bare ground are also included where present. In 2007, an additional $1 \mathrm{~m}^{2}$ nest (not shown in Fig. 4) was introduced, in order to allow joint analysis of $1 \mathrm{~m}^{2}$ plots being recorded in parallel as part of agri-environment scheme monitoring programs. This nest is located in the northernmost corner of the inner $4 \mathrm{~m}^{2}$ nest (named nest "0"). Vegetation height, aspect and slope are also recorded. Soil samples are also taken at the same time, at the site of these plots; the procedure used for recording soil samples is given by Emmett et al. (2008) and is outside the remit of the present paper. 
In arable fields where full access is not possible, for reasons of practicality species records are made from plots taken from an estimated $14 \mathrm{~m}$ square, starting $3 \mathrm{~m}$ into the crop, which avoids edge effects in most cases and minimises disturbance to the crop. Access is made using drill lines where possible in order to avoid trampling the crop. Overall cover is also estimated as in other land cover types. The relative uniformity of species within crops led to the adoption of this approach and the subsequent changes observed in species numbers in arable fields justified its use.

\section{Y plots - small, targeted or habitat plots}

These are small $(2 \times 2 \mathrm{~m})$ plots located in less common vegetation types, usually of conservation interest, often occurring in small patches not sampled by other plot types. In 2007, additional Y plots also were placed in priority habitat (Maddock, 2008) patches that had also not been sampled by any other plot in the square. The Y plots are therefore important in sampling fragments of semi-natural habitat particularly in lowland landscapes where patches may be small and embedded in a matrix of intensive farmland. These plots are placed randomly by surveyors in suitable patches of vegetation (based on rules described in Maskell et al., 2008). Of all the plots recorded, they are most similar to the approach taken when positioning quadrats during National Vegetation Classification (NVC) (Rodwell, 2006) survey, where the location of the plot is designed to represent a vegetation unit perceived to be floristically distinct and homogenous. However, protocols for locating Y plots from 1998 onwards stipulated random location from within a larger extent of vegetation type in the $1 \mathrm{~km}$ square or from a number of patches representing the mapped land cover type. The validity of statistically analysing plots located with a degree of subjectivity is an ongoing matter of debate (see for example Lájer, 2007, and Palmer, 1993, for an illustration of analytical problems but also Ross et al., 2010, for counter-argument and examples of analysing temporal change in subjectively located samples).

\section{U plots - unenclosed plots}

These plots were introduced into the CS methodology for the first time in the 1998 survey to characterise the unenclosed broad habitats (Jackson, 2000) - these being calcareous and acid grasslands; bracken; dwarf shrub heath; fen, marsh and swamp; bog; montane; supra-littoral rock and sediment; and inland rock. Up to 10 plots were established in any unenclosed broad habitat types that occurred within the square (proportional to area), again placed randomly by surveyors. The plots are $2 \times 2 \mathrm{~m}$ in all instances, regardless of the broad habitat in which they are located.

\section{B plots - boundary plots}

Boundary linear plots are recorded at a position on the boundary closest to each X plot and on a cardinal axis from it (i.e. north, south, east or west). A boundary is taken to be any linear physical feature that has a length greater than $20 \mathrm{~m}$ and which is an interface between the land cover of the $200 \mathrm{~m}^{2}$ $\mathrm{X}$ plot and any other land cover type. This might include a hedge, wall, fence, ditch or embankment. These are linear $10 \times 1 \mathrm{~m}$ plots.

\section{A plots - arable field margin plots}

Arable field margin plots were recorded for the first time in the 1998 survey. The purpose of establishing the plots was to record the arable weed population at the edge of cultivated fields and any subsequent changes. Theses plots relate only to the edge of fields and are quite distinct from the (arable) X (main) plots which are actually in the crop. They contribute an important source of biodiversity not present in the arable main plots, which cover the overall composition of arable crops because as described above, the margin is specifically excluded. The uptake of "conservation headland" options for arable field management under agri-environment schemes may further enhance species diversity in A plots. The plots are $100 \mathrm{~m}$ long by $1 \mathrm{~m}$ wide and located adjacent to B plots which border arable fields, up to a maximum of five per square. They always sample the first $1 \mathrm{~m}$ of cultivated land moving away from the perennial-dominated margin.

\section{M plots - margin plots}

M plots are small $(2 \times 2 \mathrm{~m})$ square plots and were new in the 2007 survey. They are associated with B plots where an A plot is present, and the number depends on the widths of the margins present, with up to three per field. They are designed to record the quality of new arable field margins that form part of the agri-environment agreements on farms and other margins put in without agri-environment support. These margins are additional to the cross-compliance margin (not relevant in Wales), which is a $2 \mathrm{~m}$ margin measured from the centre of the hedge. The most common types of margin likely to be encountered are perennial grass margins, with or without supplementary wildflowers. Other rarer types include, uncropped strips, usually cultivated each year (regenerating from the seedbank); wild bird seed cover, e.g. kale, quinoa; and pollen and nectar mixes, usually with a high proportion of legumes.

\section{$\mathrm{H}$ plots - hedgerow plots}

$\mathrm{H}$ plots are linear $10 \times 1 \mathrm{~m}$ plots running alongside managed woody linear features ("WLFs", hedgerows). Within H plots, species associated with the managed WLFs are recorded. When first recorded in 1978, the plot positions were located 
as close as possible to the two $\mathrm{X}$ plots in each square which were furthest apart.

\section{D plots - hedgerow diversity plots}

Hedgerow diversity plots were recorded for the first time in 1998. The overall purpose was to set up a baseline of plots to monitor woody species diversity in WLFs. One D plot is placed on each WLF in the square, up to a maximum of 10 plots. As well as providing information on woody species diversity, the data collected in $\mathrm{D}$ plots also help to provide an assessment of the condition of hedgerows and other WLFs by providing vital information about the size of the WLFs, gappiness, levels of disturbance and species composition. Each plot is $30 \mathrm{~m}$ long and includes the full width of the WLF.

\section{S/W plots - streamside plots}

The term "streamside plot" denotes linear plots which lie alongside running water features (mainly rivers and streams, but also canals and ditches). The $\mathrm{S}$ and $\mathrm{W}$ prefixes refer to the different origins of the plots: two Streamside (S) plots were established in 256 of the $1 \mathrm{~km}$ squares in 1978 , located as close as possible to the two $\mathrm{X}$ plots in each square which were furthest apart. $\mathrm{W}$ plots were up to three additional waterside plots, placed in all squares in 1990 to increase representation of other waterside types. These are linear $10 \times 1 \mathrm{~m}$ plots.

\section{R/V plots - roadside and verge plots}

The term "roadside plot" denotes those linear plots which lie alongside transport routes (mainly roads and tracks). The $\mathrm{R}$ and $\mathrm{V}$ prefixes refer to the different origins of the plots: two roadside $(\mathrm{R})$ plots were established in 256 of the $1 \mathrm{~km}$ squares in 1978, located as close as possible to the two $\mathrm{X}$ plots in each square which were furthest apart. V plots are up to three additional verge plots first placed in $1 \mathrm{~km}$ squares in 1990 to increase representation of other transport types. These are linear $10 \times 1 \mathrm{~m}$ plots.

\subsection{Plot relocation}

To analyse change, it is important to relocate the exact same sampling plot locations in successive surveys. The data from the repeated vegetation plots provide a globally unique dataset allowing large-scale yet fine-grained change in overall vegetation and the state or condition of the broad and priority habitats over time to be documented at four points over the last 29 years. There are no other national data sets that cover entire landscapes, including constituent habitats over such a long period of time. In practice, there are actually very few long-term studies of vegetation change. Those existing are usually either opportunistic, because some local recording has given a precise location, for example Dunnett

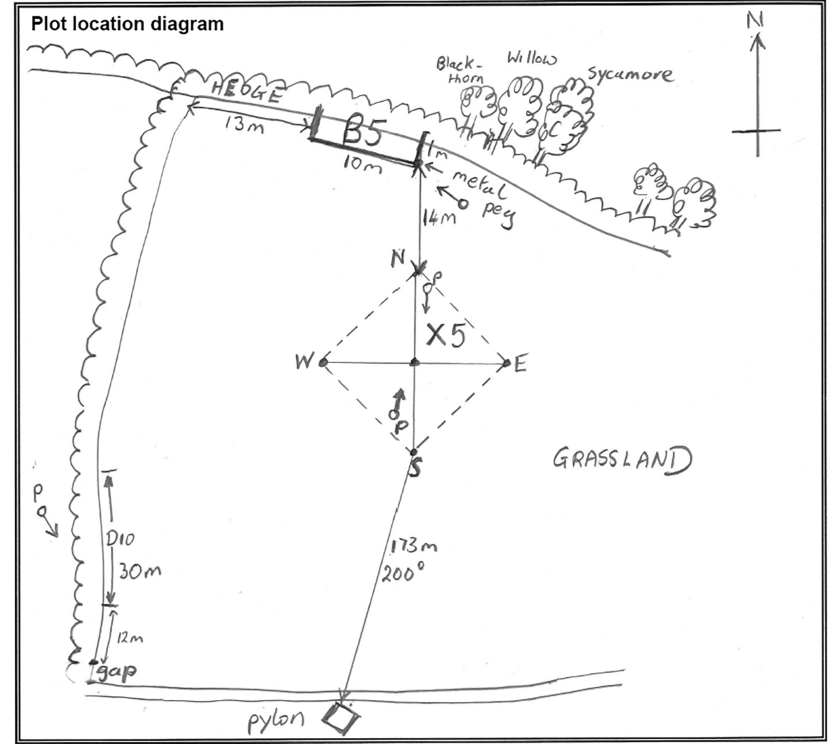

Figure 5. Example of a plot sketch map.

et al. (1998) on a roadside verge in Bibury in Gloucestershire, or pertain to specific habitats, such as the Park Grass Experiment at Rothamsted (Silvertown et al., 2006).

During the surveys, plot locations have been recorded on paper using a sketch map with measurements from distinguishing landscape features (Fig. 5), and by taking at least two photographs (see Fig. 6 for an example), preferably also including key landscape features in proximity to the plot. In addition to these, permanent metal plates or wooden stakes were introduced in the 1990 survey. In 1998, a GPS position was recorded in some remote squares, which assisted locating plots again in 2007. In 2007, the plot locations were recorded via the ruggedised field computers using the inbuilt GPS (where a GPS signal was available). Surveyors are also able to record whether the plots have been re-found adequately or otherwise. Circumstances where a plot may not be repeated might include an area becoming built-up, a feature having been removed or a land owner refusing access to the land containing the plot. Using a combination of metal plates, photographs and sketch maps, plots are estimated to have a precise relocation accuracy of 85-86\% (Prosser and Wallace, 2008). (See Prosser and Wallace, 2008, for further analysis regarding this issue.)

\section{Data quality}

Each field survey was carried out by teams of experienced botanical surveyors, and was preceded by an intensive training course, ensuring high standards and consistency of methodology, effort, identification and recording across CS according to criteria laid out in the field handbooks (Maskell et al., 2008; Barr, 1998, 1990; Bunce, 1978). During the surveys, survey teams were initially supervised and later mon- 


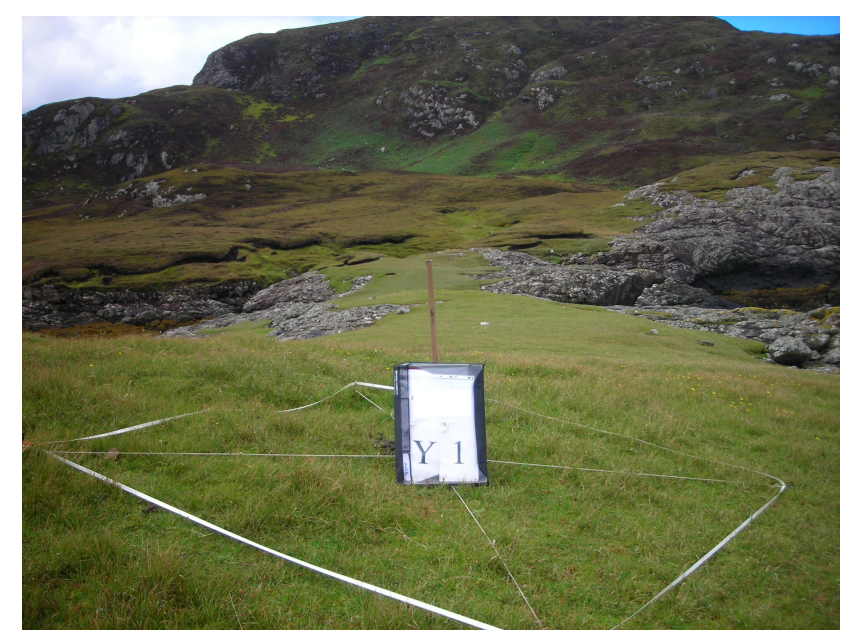

Figure 6. Example of a plot photograph.

itored by experienced project staff in order to control data quality.

Data were recorded on waterproof paper sheets in 1978, 1990 and 1998 and were consequently transferred from the original field sheets to spreadsheets, using a "double-punch" method to minimise errors in data entry. They were checked using range and format checks, and corrected to produce a final validated copy. In 2007, a new electronic data capture method was developed by the Centre for Ecology \& Hydrology and used in CS for the first time. The move to electronic methods created greater efficiency in terms of data entry and also eliminated a potentially significant source of error. Improvements to data quality also resulted from the inclusion of mandatory data entry fields for each plot.

In terms of assessing the actual level of botanical expertise in the field surveys, quality assurance (QA) reports were completed by independent botanists for the surveys in 1990, 1998 and 2007 (Prosser and Wallace, 2008, 1999, 1992). These reports have been a vital tool in assessing and validating the quality of the botanical record in each CS. Paired species records from a subset of plots (the QA plots) have been analysed in a number of ways to measure the consistency of recording effort within each survey. In all three surveys the QA assessors found more species than the CS field teams, yet in both the 1990 and 1998 assessments, the results showed that there was no bias in the species composition of the vegetation recorded, as described by Prosser and Wallace (2008). In 2007, the QA analysis appeared to show a decline in the quality of botanical recording. However, this was possibly due to less comprehensive recording of common bryophytes than in previous surveys, but subsequent analyses determined that the bias was not significant (Scott et al., 2008; Smart et al., 2008). Users of the data could remove bryophytes from analyses if they were concerned by this feature of the database. Errors attributable to use of the electronic data capture software were minor and not significant (Prosser and Wallace, 2008).

\section{Methodological development}

The now established method of CS, using a stratified random series of samples, was developed over two decades by what was then the Institute of Terrestrial Ecology as described by Sheail and Bunce (2003). The first national series of stratified random samples was the 1971 Woodland Survey (Wood et al., 2015) and strategic sampling at the landscape level was subsequently used successfully in defining the range of variation in vegetation in regional surveys in Cumbria and Shetland (Bunce and Smith, 1978; Wood and Bunce, 2016). These methods have now been proven as a successful national vegetation monitoring strategy incorporating four surveys across nearly 30 years. Minor modifications to the methods have more recently been used for a comprehensive ecological survey of Wales (2013-), the Glastir Monitoring and Evaluation Programme (GMEP) (Emmett and GMEP team, 2014).

Since the first survey in 1978, the methods have gradually developed to incorporate contemporary technologies, for example, the introduction of GPS in 1998, and the use of ruggedised field computers with internal GPS to record the location and species composition of the vegetation plots in 2007. Over time, the development of geographical information systems (GISs) has greatly facilitated both the efficiency of storage of ecological spatial data, and also the types of analyses that can be undertaken. It is now possible to perform much wider analyses than previously, using a range of ancillary explanatory datasets, as described in the Integrated Assessment Report for the Countryside Survey (Smart et al., 2010a). The underlying principles of the Countryside Survey methodology provide an ideal framework for the planning of large-scale monitoring, not only in Britain but across Europe and worldwide, as discussed in Wood and Bunce (2016).

It has now been a decade since the last survey, and current funding constraints mean that the traditional cycle of large one-off national surveys taking place roughly 1 year in every decade is likely to need revising. Various options are available for repeating all or parts of the survey. A rolling program over several years is attractive because it spreads the financial load. It also allows inter-annual effects of differences in the weather and variation in recorder effort to be more robustly estimated and separated from long-term trends. A Markov chain approach could be used to examine possible outcomes from the time series of plots (for example, Balzter, 2000). Between 2013 and 2016, CS methods have already been applied in an annual rolling program to monitor the effects of the Glastir agri-environment scheme across Wales (https://gmep.wales/).

Plot numbers could be rationalised according to the desired results. Using previous data, it is possible to identify 
the optimal numbers of plots required by plot type, vegetation type and region in order to provide data on specific criteria, for example, species richness change at Great Britain level by plot type. Less costly options for maximising the use of the existing surveys in future surveillance have been suggested as part of the Future Options review for national monitoring in Wales (Emmett et al., 2016a). However, the feasibility of these options has yet to be determined.

\section{Use of the data}

The Countryside Survey provides a unique and well-utilised resource, offering potential for a wide range of analyses at different temporal and spatial scales. A major benefit of the programme is the co-registration of a wide range of recorded ecological variables (i.e. soil, vegetation, land use, freshwater). In parallel to its direct policy application, a vibrant and productive research agenda has used CS vegetation data often in combination with other datasets to produce improved understanding about the significance and causes of largescale but finely resolved ecological change in Britain. Questions can be broadly categorised as "What has changed and where?", "What are the drivers of change?", "Is the change important?" and "Can we use forecast future change?".

As the data from the vegetation plots are intended to be representative of the larger areas in which they are located (i.e. land class), the restrictions on the precise locations of the plots need not restrict potential analyses. For example, the design of the survey is such that the data are intended to be extrapolated to a land class and, ultimately, a national level. Data may also be used in conjunction with other co-located variables (for example, soils data; Emmett et al., 2016c) to examine inter-relationships.

\subsection{Key findings}

Key findings and fundamental questions about the extent and condition of terrestrial broad/priority habitats are addressed in the reporting round to policy makers that has followed each survey (e.g. Haines-Young et al., 2000; Carey et al., 2008; Smart et al., 2009; Norton et al., 2009; Emmett et al., 2010; Bunce, 1979; Barr et al., 1993) and elsewhere (Smart et al., 2003; Norton, 2012). Overall changes in plant species richness formed part of a trend in species loss $(8 \%)$ across Great Britain between 1978 and 2007 (although this measure is a simple one, it is readily understood and appreciated by policy makers; however, it does need to be supported by the more detailed ecological analyses described in Sect. 7.2). Woody species increased in vegetation associated with landscape boundaries by $14 \%$ between 1998 and 2007 and by nearly $80 \%$ in Great Britain between 1978 and 2007.

The most commonly recorded species in CS, ryegrass (Lolium perenne), was the same in 2007 as in both 1998 and 1990 . The top 10 most commonly recorded species in 2007 also included stinging nettle (Urtica dioica), hawthorn
(Crataegus monogyna), and bramble (Rubus fruticosus) all of which increased between 1998 and 2007.

Long-term change in vegetation from 1978 to 2007 has also been assessed using a range of condition measures (Table 2). In open countryside in Great Britain, between 1998 and 2007 plant species that prefer wetter conditions increased, while those preferring fertile soils and high $\mathrm{pH}$ decreased. In the period 1978 to 2007, an increase in species preferring wetter conditions was the most consistent signal in plots sampling different parts of the landscape across all countries.

\subsection{Wider uses of data to date}

After CS in 2007, the data continued to have a substantial impact, contributing to many areas of the UK National Ecosystem Assessment (NEA) (Watson et al., 2011), which articulated ecological status and change in terms of ecosystem services (ESs). This was the first analysis of the UK's natural environment in terms of the benefits it provides to society and continuing economic prosperity. Soils, vegetation, headwater stream and land cover data from Countryside Survey were also jointly analysed with a range of explanatory variable datasets to produce new indicators and analysis of potential ES delivery in the Integrated Assessment project that marked the final phase of reporting after the 2007 survey (Smart et al., 2010a; Norton et al., 2012).

Subsequently, CS plot data have been used in conjunction with land cover map data (Morton et al., 2011) and wider environmental datasets as part of a natural capital mapping tool which has been used, alongside other modelling techniques, to produce maps of natural capital for policy makers (https://eip.ceh.ac.uk/naturalengland-ncmaps) and to help in understanding the factors influencing spatial differences in ES delivery (Henrys et al., 2015a; Norton et al., 2016). Analysis demonstrated fundamental trade-offs between ecosystem productivity and soil carbon concentration while a range of biodiversity indicators appeared to peak at intermediate levels of productivity (Maskell et al., 2013). The novel inclusion of dynamic ecosystem model estimates of productivity provided both the foundation and research direction for ongoing work that has sought to develop dynamic models of natural capital and ES delivery (Emmett et al., 2016b; Smart et al., 2017; Rowe et al., 2016).

CS datasets have also made a unique contribution to the development of plant species niche models for ecosystem dominants and many rare species in Britain (Hill et al., 2017; Henrys et al., 2015b, c; Smart et al., 2010b, c). The policy motivation for this originally was detection and modelling of the effects of atmospheric pollutant deposition (De Vries et al., 2010; Stevens et al., 2016).

The statistically robust, national scale of the CS vegetation data makes it ideally placed to detect realistically scaled relationships between global change drivers, such as pollutant deposition (for example van den Berg et al., 2016; Maskell et 
Table 2. Change in the characteristics of all types of vegetation in $200 \mathrm{~m}^{2}$ main plots in Great Britain between 1978 and 2007. Arrows denote significant change $(p<0.05)$ in the direction shown.

\begin{tabular}{lrrrrc}
\hline & & Mean values & & $\begin{array}{c}\text { Direction of significant } \\
\text { changes 1978-2007 }\end{array}$ \\
\hline Vegetation condition measures & 1978 & 1990 & 1998 & 2007 & GB \\
\hline Species richness (no. of species) & 17.1 & 16.5 & 16.2 & 15.7 & $\downarrow$ \\
Light score & 6.98 & 6.95 & 6.95 & 6.95 & \\
Fertility score & 4.53 & 4.64 & 4.61 & 4.55 & \\
Ellenberg pH score* & 5.07 & 5.17 & 5.14 & 5.09 & $\uparrow$ \\
Moisture score & 5.75 & 5.71 & 5.77 & 5.82 & $\uparrow$ \\
\hline
\end{tabular}

* Ellenberg (1988)

al., 2010; Smart et al., 2005a; Stevens et al., 2009) as well as other drivers of eutrophication and land management change (Smart et al., 2012, 2002, 2003, 2005b, 2006a, b). While research into the causes and consequences of eutrophication was a response to clear policy interest, analysis of CS vegetation data has also contributed evidence in response to concerns over the causes and consequences of loss of pollinators in north-west Europe and Britain (Smart et al., 2000; Carvell et al., 2006; Baude et al., 2016).

Habitat specific studies, such as those relating to woodlands (for example Petit et al., 2004; Kimberley et al., 2013, 2016) and hedgerows, McCollin et al., 2000; Garbutt and Sparks, 2002; Critchley et al., 2013) have been facilitated through the use of CS data. Interesting conclusions have been made through use of the data with regard to increasing numbers of non-native invasive species (Chytrý et al., 2008; Maskell et al., 2006).

The results and information derived from CS can often be set into wider contexts, for example, European (Chytrý et al., 2008; Metzger et al., 2013), or in relation to other monitored datasets (Rose et al., 2016; Scott et al., 2010; Carey et al., 2002; Rhodes et al., 2015).

Data from the 1990 survey were used in the development of a statistically based British vegetation classification, termed the Countryside Vegetation Classification (CVS) as described in Bunce et al. (1999). This led to the development of a computer system termed MAVIS (Modular Analysis of Vegetation Information System), enabling classification of any lists of species from plots into the CVS but also into the phytosociological classes of the National Vegetation Classification (Rodwell, 2006). The software is publicly available (Smart and DART Computing, 2017).

\section{Data availability}

The datasets have been assigned digital object identifiers and users of the data must reference the data as follows:

- Barr, C. J., Bunce, R. G. H., Smart, S. M., and Whittaker, H. A.: Countryside Survey 1978 vegetation plot data, NERC Environmental Information Data Centre, https://doi.org/10.5285/67bbfabb-d981-4ced-b7e7225205de9c96, 2014.

- Barr, C. J., Bunce, R. G. H., Gillespie, M. K., Hallam, C. J., Howard, D. C., Maskell, L. C., Ness, M. J., Norton, L. R., Scott, R. J., Smart, S. M., Stuart, R. C., and Wood, C. M.: Countryside Survey 1990 vegetation plot data, NERC Environmental Information Data Centre, https://doi.org/10.5285/26e797925ffc-4116-9ac7-72193dd7f191, 2014.

- Barr, C. J., Bunce, R. G. H., Gillespie, M. K., Howard, D. C., Maskell, L. C., Norton, L. R., Scott, R. J., Shield, E. R., Smart, S. M., Stuart, R. C., Watkins, J. W., and Wood, C. M.: Countryside Survey 1998 vegetation plot data, NERC Environmental Information Data Centre, https://doi.org/10.5285/07896bb2-7078468c-b56d-fb8b41d47065, 2014.

- Bunce, R. G. H., Carey, P. D., Maskell, L. C., Norton, L. R., Scott, R. J., Smart, S. M., and Wood, C. M.: Countryside Survey 2007 vegetation plot data, NERC Environmental Information Data Centre, https://doi.org/10.5285/57f97915-8ff1-473b-8c772564cbd747bc, 2014.

The datasets are available from the CEH Environmental Information Data Centre Catalogue (https://eip.ceh.ac.uk/data). Datasets are provided under the terms of the Open Government Licence (http://eidchub.ceh.ac.uk/administration-folder/tools/ ceh-standard-licence-texts/ceh-open-government-licence/ plain, http://www.nationalarchives.gov.uk/doc/ open-government-licence/version/3/). The metadata are stored in the ISO 19115 (2003) schema (International Organization for Standardization, 2015) in the UK Gemini 2.1 profile (UK GEMINI, http://www.agi.org.uk/join-us/ agi-groups/standards-committee/uk-gemini). Users of the datasets will find the following documents useful (supplied as supporting documentation with the datasets): the Sampling Strategy for Countryside Survey (Barr and Wood, 
2011) and the field survey handbooks (Barr, 1990, 1998; Bunce, 1978; Maskell et al., 2008).

\section{Conclusions}

The vegetation data recorded during the Countryside Survey of Great Britain are an invaluable national resource, which, over the years, has been exploited in a large number of ways. The data are collected in a statistically robust and quality controlled manner, follow standard, repeatable methods and cover wide temporal and spatial scales. As consequence of this, the data present a unique opportunity for inclusion in a wide range of analyses and models. The intention is that a repeat survey will be undertaken in the near future (indeed a sub-sample of plots (the majority being located in Wales) have already been surveyed in the summer of 2016, largely as part of the Glastir Monitoring and Evaluation Programme, Emmett and GMEP team, 2014). As a decade has now passed since the most recent full survey, an addition to this long-term national resource is becoming increasingly timely, particularly in these current times of political, socio-economic and climatic change.

Author contributions. CMW prepared the manuscript with significant contributions from all co-authors, and is the current database manager for the Land Use Research Group at CEH Lancaster. RGHB designed the sampling framework and survey strategy in 1978. RGHB, SMS, LCM, LRN and DCH have all been part of the Countryside Survey co-ordination team for at least one survey, with WAS and PAH contributing statistical support.

Competing interests. The authors declare that they have no conflict of interest.

Acknowledgements. We thank all the land owners who kindly gave permission to survey their holdings in the survey sample squares in 1978, 1990, 1998 and 2007. Without their co-operation and assistance the Countryside Survey would not exist. We also acknowledge and thank all the field surveyors involved in each field campaign. We are grateful to two anonymous reviewers and the editor, Falk Huettmann, whose comments improved the manuscript considerably.

The most recent Countryside Survey was funded largely by the Natural Environment Research Council, the Department for Environment Food and Rural Affairs and the Scottish and Welsh Governments.

Edited by: Falk Huettmann

Reviewed by: two anonymous referees

\section{References}

Balzter, H.: Markov chain models for vegetation dynamics, Ecol. Model., 126, 139-154, https://doi.org/10.1016/S03043800(00)00262-3, 2000.

Barr, C.: Countryside Survey 1990 field handbook, Institute of Terrestrial Ecology, Grange-over-Sands, 1990.

Barr, C. J., Bunce, R. G. H., Clarke, R. T., Fuller, R. M., Furse, M. T., Gillespie, M. K., Groom, G. B., Hallam, C. J., Hornung, M., Howard, D. C., and Ness, M. J.: Countryside Survey 1990: main report, in: Countryside 1990, Vol. 2, Department of the Environment, London, 1993.

Barr, C. J.: Countryside Survey 2000 Field Handbook, Institute of Terrestrial Ecology, Grange-over-Sands, 1998.

Barr, C. J. and Wood, C. M.: The Sampling Strategy for Countryside Survey (up to 2007), 2nd Edn., Detr Contract No. CR0212, Lancaster, 2011.

Barr, C. J., Bunce, R. G. H., Gillespie, M. K., Hallam, C. J., Howard, D. C., Maskell, L. C., Ness, M. J., Norton, L. R., Scott, R. J., Smart, S. M., Stuart, R. C., and Wood, C. M.: Countryside Survey 1990 vegetation plot data, NERC Environmental Information Data Centre, https://doi.org/10.5285/26e79792-5ffc-4116-9ac772193dd7f191, 2014a.

Barr, C. J., Bunce, R. G. H., Gillespie, M. K., Howard, D. C., Maskell, L. C., Norton, L. R., Scott, R. J., Shield, E. R., Smart, S. M., Stuart, R. C., Watkins, J. W., and Wood, C. M.: Countryside Survey 1998 vegetation plot data, NERC Environmental Information Data Centre, https://doi.org/10.5285/07896bb2-7078468c-b56d-fb8b41d47065, 2014b.

Barr, C. J., Bunce, R. G. H., Smart, S. M., and Whittaker, H. A.: Countryside Survey 1978 vegetation plot data, NERC Environmental Information Data Centre, https://doi.org/10.5285/67bbfabb-d981-4ced-b7e7225205de9c96, 2014c.

Baude, M., Kunin, W. E., Boatman, N. D., Conyers, S., Davies, N., Gillespie, M. A., Morton, R. D., Smart, S. M., and Memmott, J.: Historical nectar assessment reveals the fall and rise of floral resources in Britain, Nature, 530, 85-88, https://doi.org/10.1038/nature16532, 2016.

Betts, M. G., Ganio, L. M., Huso, M. M. P., Som, N. A., Huettmann, F., Bowman, J., and Wintle, B. A.: Comment on "Methods to account for spatial autocorrelation in the analysis of species distributional data: a review", Ecography, 32, 374-378, https://doi.org/10.1111/j.1600-0587.2008.05562.x, 2009.

Bunce, R., Barr, C., Gillespie, M., Howard, D., Scott, W., Smart, S., van de Poll, H., and Watkins, J.: ECOFACT 1 - Vegetation of the British Countryside, HMSO, London, 1999.

Bunce, R. G. H.: UK Ecological Survey. Handbook of Field Methods, Insitute of Terrestrial Ecology, Grange-over-Sands, 1978.

Bunce, R. G. H.: Ecological survey of Britain, Institute of Terrestrial Ecology, Cambridge, 74-75, 1979.

Bunce, R. G. H. and Shaw, M. W.: National survey of semi-natural woodlands, in: Merlewood Research Station Report for 1970-72, The Nature Conservancy, Grange-over-Sands, 1973.

Bunce, R. G. H. and Smith, R. S.: An ecological survey of Cumbria, Structure Plan Working Paper, 4, Cumbria County Council and Lake District Special Planning Board, Kendal 1978.

Bunce, R. G. H., Barr, C. J., Clarke, R. T., Howard, D. C., and Lane, A. M. J.: ITE land classification of Great 
Britain 1990, NERC Environmental Information Data Centre, https://doi.org/10.5285/ab320e08-faf5-48e1-9ec977a213d2907f, 1990.

Bunce, R. G. H., Barr, C. J., Clarke, R. T., Howard, D. C., and Lane, A. M. J.: ITE Merlewood Land Classification of Great Britain, J. Biogeogr., 23, 625-634, https://doi.org/10.1111/j.13652699.1996.tb00023.x, 1996a.

Bunce, R. G. H., Barr, C. J., Clarke, R. T., Howard, D. C., and Lane, A. M. J.: Land classification for strategic ecological survey, J. Environ. Manage., 47, 37-60, https://doi.org/10.1006/jema.1996.0034, 1996b.

Bunce, R. G. H., Barr, C. J., Gillespie, M. K., and Howard, D. C.: The ITE Land Classification: providing an environmental stratification of Great Britain, Environ. Monit. Assess., 39, 39-46, https://doi.org/10.1007/978-94-009-1653-1_5, 1996c.

Bunce, R. G. H., Carey, P. D., Elena-Rossello, R., Orr, J., Watkins, J., and Fuller, R.: A comparison of different biogeographical classifications of Europe, Great Britain and Spain, J. Environ. Manage., 65, 121-134, https://doi.org/10.1006/jema.2002.0533, 2002.

Bunce, R. G. H., Carey, P. D., Maskell, L. C., Norton, L. R., Scott, R. J., Smart, S. M., and Wood, C. M.: Countryside Survey 2007 vegetation plot data, NERC Environmental Information Data Centre, https://doi.org/10.5285/57f97915-8ff1-473b-8c772564cbd747bc, 2014.

Burton, A. C., Huggard, D., Bayne, E., Schieck, J., Sólymos, P., Muhly, T., Farr, D., and Boutin, S.: A framework for adaptive monitoring of the cumulative effects of human footprint on biodiversity, Environ. Monit. Assess., 186, 3605-3617, 2014.

Carey, P., Barnett, C., Greenslade, P., Hulmes, S., Garbutt, R., Warman, E., Myhill, D., Scott, R., Smart, S., and Manchester, S.: A comparison of the ecological quality of land between an English agri-environment scheme and the countryside as a whole, Biol. Conserv., 108, 183-197, https://doi.org/10.1016/S00063207(02)00105-2, 2002.

Carey, P. D., Wallis, S., Chamberlain, P. M., Cooper, A., Emmett, B. A., Maskell, L. C., McCann, T., Murphy, J., Norton, L. R., Reynolds, B., Scott, W. A., Simpson, I. C., Smart, S. M., and Ullyett, J. M.: Countryside Survey: UK Results from 2007, NERC/Centre for Ecology \& Hydrology, Lancaster, 2008.

Carvell, C., Roy, D. B., Smart, S. M., Pywell, R. F., Preston, C. D., and Goulson, D.: Declines in forage availability for bumblebees at a national scale, Biol. Conserv., 132, 481-489, https://doi.org/10.1016/j.biocon.2006.05.008, 2006.

Chytrý, M., Maskell, L. C., Pino, J., Pyšek, P., Vilà, M., Font, X., and Smart, S. M.: Habitat invasions by alien plants: a quantitative comparison among Mediterranean, subcontinental and oceanic regions of Europe, J. Appl. Ecol., 45, 448-458, https://doi.org/10.1111/j.1365-2664.2007.01398.x, 2008.

Cooper, A., McCann, T., and Rogers, D.: Northern Ireland countryside survey 2007: broad habitat change 1998-2007, Northern Ireland Environment Agency, Coleraine, 2009.

Critchley, C., Wilson, L., Mole, A., Norton, L., and Smart, S.: A functional classification of herbaceous hedgerow vegetation for setting restoration objectives, Biodivers. Conserv., 22, 701-717, https://doi.org/10.1007/s10531-013-0440-5, 2013.

De Vries, W., Wamelink, G., Van Dobben, H., Kros, J., Reinds, G., Mol-Dijkstra, J., Smart, S., Evans, C., Rowe, E., and Belyazid, S.: Use of dynamic soil-vegetation models to assess impacts of nitrogen deposition on plant species composition: an overview, Ecol. Appl., 20, 60-79, https://doi.org/10.1890/08-1019.1, 2010.

Dramstad, W. E., Fjellstad, W., Strand, G.-H., Mathiesen, H. F., Engan, G., and Stokland, J. N.: Development and implementation of the Norwegian monitoring programme for agricultural landscapes, J. Environ. Manage., 64, 49-63, 2002.

Dunnett, N., Willis, A., Hunt, R., and Grime, J.: A 38-year study of relations between weather and vegetation dynamics in road verges near Bibury, Gloucestershire, J. Ecol., 86, 610-623, https://doi.org/10.1046/j.1365-2745.1998.00297.x, 1998.

Ellenberg, H.: Vegetation ecology of central Europe, Cambridge University Press, Cambridge, 1988.

Emmett, B., Frogbrook, Z., Chamberlain, P., Griffiths, R., Pickup, R., Poskitt, J., Reynolds, B., Rowe, E., Spurgeon, D., and Rowland, P.: CS Technical Report No. 3/07: Soils Manual, Centre for Ecology \& Hydrology Wallingford, UK, 2008.

Emmett, B. A., Reynolds, B., Chamberlain, P. M., Rowe, E., Spurgeon, D., Brittain, S. A., Frogbrook, Z., Hughes, S., Lawlor, A. J., Poskitt, J., Potter, E., Robinson, D. A., Scott, A., Wood, C., and Woods, C.: Countryside Survey: Soils Report from 2007, Centre for Ecology \& Hydrology, Wallingford, UK, 2010.

Emmett, B. E. and GMEP team: Glastir Monitoring \& Evaluation Programme, First Year Annual Report to Welsh Government (Contract reference: C147/2010/11), NERC/Centre for Ecology \& Hydrology, Bangor, 442 pp., 2014.

Emmett, B., Bell, C., Chadwick, D., Cheffings, C., Henrys, P., Prosser, H., Siriwardena, G., Smart, S., and Williams, B.: Options for a new integrated natural resources monitoring framework for Wales, Phase 1 project report, NERC/Centre for Ecology \& Hydrology, Bangor, UK, 2016a.

Emmett, B., Cooper, D., Smart, S., Jackson, B., Thomas, A., Cosby, B., Evans, C., Glanville, H., McDonald, J. E., and Malham, S. K.: Spatial patterns and environmental constraints on ecosystem services at a catchment scale, Sci. Total Environ., 572, 15861600, https://doi.org/10.1016/j.scitotenv.2016.04.004, $2016 \mathrm{~b}$.

Emmett, B., Reynolds, B., Chamberlain, P. M., Rowe, E., Spurgeon, D., Brittain, S. A., Frogbrook, Z., Hughes, S., Lawlor, A. J., Poskitt, J., Potter, E., Robinson, D. A., Scott, A., Wood, C. M., Woods, C.: Soil physico-chemical properties 2007, Countryside Survey, NERC Environmental Information Data Centre, available at: https://doi.org/10.5285/ 79669141-cde5-49f0-b24d-f3c6a1a52db8, 2016c.

Garbutt, R. and Sparks, T.: Changes in the botanical diversity of a species rich ancient hedgerow between two surveys (1971-1998), Biol.Conserv., 106, 273-278, https://doi.org/10.1016/S0006-3207(01)00253-1, 2002.

Haines-Young, R. H., Barr, C. J., Black, H. I. J., Briggs, D. J., Bunce, R. G. H., Clarke, R. T., Cooper, A., Dawson, F. H., Firbank, L. G., Fuller, R. M., Furse, M. T., Gillespie, M. K., Hill, R., Hornung, M., Howard, D. C., McCann, T., Morecroft, M. D., Petit, S., Sier, A. R. J., Smart, S. M., Smith, G. M., Stott, A. P., Stuart, R. C., and Watkins, J. W.: Accounting for nature: assessing habitats in the UK countryside, London DETR, 2000.

Henrys, P., Bee, E., Watkins, J., Smith, N., and Griffiths, R.: Mapping natural capital: optimising the use of national scale datasets, Ecography, 38, 632-638, https://doi.org/10.1111/ecog.00402, 2015a.

Henrys, P., Smart, S., Rowe, E., Jarvis, S., Fang, Z., Evans, C., Emmett, B., and Butler, A.: Niche models for British plants and 
lichens obtained using an ensemble approach, New J. Botany, 5, 89-100, 2015b.

Henrys, P. A., Butler, A., Jarvis, S., Smart, S. M., and Fang, Z.: MultiMOVE Model: Ensemble niche modelling of British vegetation v2.0.1, NERC Environmental Information Data Centre, https://doi.org/10.5285/94ae1a5a-2a28-4315-8d4b35ae964fc3b9, 2015c.

Hill, L., Hector, A., Hemery, G., Smart, S., Tanadini, M., and Brown, N.: Abundance distributions for tree species in Great Britain: a two-stage approach to modeling abundance using species distribution modeling and random forest, Ecol. Evol., 7, 1043-1056, https://doi.org/10.1002/ece3.2661, 2017.

Hill, M. O. and Šmilauer, P.: TWINSPAN for Windows version 2.3., Centre for Ecology and Hydrology, University of South Bohemia, Wallingford, 2005.

Hintermann, U., Weber, D., Zangger, A., and Schmill, J.: Biodiversity Monitoring in Switzerland, BDM - Interim Report, Berne, 2002.

Hope-Simpson, J.: On the errors in the ordinary use of subjective frequency estimations in grassland, J. Ecol., 28, 193-209, https://doi.org/10.2307/2256169, 1940.

International Organization for Standardization, ISO 19115:2003: http://www.iso.org/iso/catalogue_detail.htm?csnumber=26020 (last access: 12 October 2015), 2015.

Jackson, D.: Guidance on the Interpretation of the Biodiversity Broad Habitat Classification (Terrestrial and Freshwater Types): Definitions and the Relationship with Other Habitat Classifications (JNCC Report, No 307), JNCC, available at: http://jncc. defra.gov.uk/page-2433, 73 pp., 2000.

Jones, H. E. and Bunce, R. G. H.: A preliminary classification of the climate of Europe from temperature and precipitation records, J. Environ. Manage., 20, 17-29, 1985.

Kimberley, A., Blackburn, G. A., Whyatt, J. D., Kirby, K., and Smart, S. M.: Identifying the trait syndromes of conservation indicator species: how distinct are British ancient woodland indicator plants from other woodland species?, Appl. Veg. Sci., 16, 667-675, https://doi.org/10.1111/avsc.12047, 2013.

Kimberley, A., Blackburn, G. A., Whyatt, J. D., and Smart, S. M.: How well is current plant trait composition predicted by modern and historical forest spatial configuration?, Ecography, 39, 6776, https://doi.org/10.1111/ecog.01607, 2016.

Lájer, K.: Statistical tests as inappropriate tools for data analysis performed on non-random samples of plant communities, Folia Geobotanica, 42, 115-122, https://doi.org/10.1007/BF02893878, 2007.

Maddock, A.: UK Biodiversity Action Plan; Priority Habitat Descriptions, available at: http://jncc.defra.gov.uk/PDF/UKBAP_ PriorityHabitatDesc-Rev2011.pdf, 2008.

Maskell, L., Firbank, L., Thompson, K., Bullock, J., and Smart, S.: Interactions between non-native plant species and the floristic composition of common habitats, J. Ecol., 94, 1052-1060, https://doi.org/10.1111/j.1365-2745.2006.01172.x, 2006.

Maskell, L. C., Norton, L. R., Smart, S. M., Scott, R., Carey, P. D., Murphy, J., Chamberlain, P. M., Wood, C. M., Bunce, R. G. H., and Barr, C. J.: Vegetation Plots Handbook CS Technical Report No. 2/07, Centre for Ecology and Hydrology, Lancaster, 2008.

Maskell, L. C., Smart, S. M., Bullock, J. M., Thompson, K., and Stevens, C. J.: Nitrogen deposition causes widespread loss of species richness in British habitats, Glob. Change Biol., 16, 671679, https://doi.org/10.1111/j.1365-2486.2009.02022.x, 2010.

Maskell, L. C., Crowe, A., Dunbar, M. J., Emmett, B., Henrys, P., Keith, A. M., Norton, L. R., Scholefield, P., Clark, D. B., and Simpson, I. C.: Exploring the ecological constraints to multiple ecosystem service delivery and biodiversity, J. Appl. Ecol., 50, 561-571, https://doi.org/10.1111/1365-2664.12085, 2013.

McCollin, D., Jackson, J., Bunce, R., Barr, C., and Stuart, R.: Hedgerows as habitat for woodland plants, J. Environ. Manage., 60, 77-90, https://doi.org/10.1006/jema.2000.0363, 2000.

Metzger, M., Bunce, R., Leemans, R., and Viner, D.: Projected environmental shifts under climate change: European trends and regional impacts, Environ. Conserv., 35, 64-75, 2008.

Metzger, M. J., Brus, D. J., Bunce, R. G. H., Carey, P. D., Gonçalves, J., Honrado, J. P., Jongman, R. H. G., Trabucco, A., and Zomer, R.: Environmental stratifications as the basis for national, European and global ecological monitoring, Ecol. Indic., 33, 26-35, https://doi.org/10.1016/j.ecolind.2012.11.009, 2013. Morton, D., Rowland, C., Wood, C., Meek, L., Marston, C., Smith, G., Wadsworth, R., and Simpson, I.: Final Report for LCM2007 - the new UK land cover map, NERC/Centre for Ecology \& Hydrology, WallingfordCS Technical Report No. 9/07, 2011.

Norton, L., Inwood, H., Crowe, A., and Baker, A.: Trialling a method to quantify the "cultural services" of the English landscape using Countryside Survey data, Land Use Policy, 29, 449455, https://doi.org/10.1016/j.landusepol.2011.09.002, 2012.

Norton, L., Greene, S., Scholefield, P., and Dunbar, M.: The importance of scale in the development of ecosystem service indicators?, Ecol. Indic., 61, 130-140, https://doi.org/10.1016/j.ecolind.2015.08.051, 2016.

Norton, L. R., Murphy, J., Reynolds, B., Marks, S., and Mackey, E. C.: Countryside Survey: Scotland results from 2007, Centre for Ecology \& Hydrology, Wallingford, 2009.

Norton, L. R., Maskell, L. C., Smart, S. S., Dunbar, M. J., Emmett, B. A., Carey, P. D., Williams, P., Crowe, A., Chandler, K., Scott, W. A., and Wood, C. M.: Measuring stock and change in the GB countryside for policy: key findings and developments from the Countryside Survey 2007 field survey, J. Environ. Manage., 113 , 117-127, https://doi.org/10.1016/j.jenvman.2012.07.030, 2012.

Ortega, M., Guerra, C., Honrado, J. P., Metzger, M. J., Bunce, R. G. H., and Jongman, R. H. G.: Surveillance of habitats and plant diversity indicators across a regional gradient in the Iberian Peninsula, Ecol. Indic., 33, 36-44, https://doi.org/10.1016/j.ecolind.2012.12.004, 2013.

Palmer, M. W.: Potential biases in site and species selection for ecological monitoring, Environ. Monit. Assess., 26, 277-282, https://doi.org/10.1007/BF00547504, 1993.

Petit, S., Griffiths, L., Smart, S. S., Smith, G. M., Stuart, R. C., and Wright, S. M.: Effects of area and isolation of woodland patches on herbaceous plant species richness across Great Britain, Landsc. Ecol., 19, 463-471, https://doi.org/10.1023/B:LAND.0000036141.30359.53, 2004.

Prosser, M. V. and Wallace, H. L.: Countryside Survey 1990 Quality Assurance Exercise. Report to Institute of Terrestrial Ecology, Merlewood Research Station, Canon Pyon, Herefordshire, 1992.

Prosser, M. V. and Wallace, H. L.: Countryside Survey 2000 Quality Assurance Exercise. Report to Institute of Terrestrial Ecology, 
Merlewood Research Station. Second draft, Canon Pyon, Herefordshire, 1999.

Prosser, M. V. and Wallace, H. L.: Quality Assurance Exercise, Report to Centre of Ecology \& Hydrology, Lancaster, 2008.

Rhodes, C. J., Henrys, P., Siriwardena, G. M., Whittingham, M. J., and Norton, L. R.: The relative value of field survey and remote sensing for biodiversity assessment, Methods Ecol. Evol., 6, 772-781, https://doi.org/10.1111/2041-210X.12385, 2015.

Rodwell, J. S.: National vegetation classification: Users' handbook, Joint Nature Conservation Committee, Peterborough, 2006.

Rose, R., Monteith, D. T., Henrys, P., Smart, S., Wood, C., Morecroft, M., Andrews, C., Beaumont, D., Benham, S., and Bowmaker, V.: Evidence for increases in vegetation species richness across UK Environmental Change Network sites linked to changes in air pollution and weather patterns, Ecol. Indic., 68, 52-62, https://doi.org/10.1016/j.ecolind.2016.01.005, 2016.

Ross, L. C., Woodin, S. J., Hester, A., Thompson, D. B., and Birks, H. J. B.: How important is plot relocation accuracy when interpreting re-visitation studies of vegetation change?, Plant. Ecol. Divers, 3, 1-8, https://doi.org/10.1080/17550871003706233, 2010.

Rowe, E. C., Ford, A. E. S., Smart, S. M., Henrys, P. A., and Ashmore, M. R.: Using qualitative and quantitative methods to choose a habitat quality metric for air pollution policy evaluation, PLOS ONE, 11, e0161085, https://doi.org/10.1371/journal.pone.0161085, 2016.

Scott, W., Morecroft, M., Taylor, M., and Smart, S.: Countryside Survey-Environmental Change Network link, Centre for Ecology and Hydrology, Wallingford, UK, 2010.

Scott, W. A., Smart, S. M., and Clarke, R.: Quality Assurance Report: QA and bias in vegetation recording, Centre for Ecology and Hydrology, Lancaster, 2008.

Sheail, J. and Bunce, R. G. H.: The development and scientific principles of an environmental classification for strategic ecological survey in the United Kingdom, Environ. Conserv., 30, 147-159, https://doi.org/10.1017/S0376892903000134, 2003.

Silvertown, J., Poulton, P., Johnston, E., Edwards, G., Heard, M., and Biss, P. M.: The Park Grass Experiment 18562006: its contribution to ecology, J. Ecol., 94, 801-814, https://doi.org/10.1111/j.1365-2745.2006.01145.x, 2006.

Smart, S., Clarke, R., Van De Poll, H., Robertson, E., Shield, E., Bunce, R., and Maskell, L.: National-scale vegetation change across Britain; an analysis of sample-based surveillance data from the Countryside Surveys of 1990 and 1998, J. Environ. Manage., 67, 239-254, https://doi.org/10.1016/S03014797(02)00177-9, 2003.

Smart, S., Ashmore, M., Hornung, M., Scott, W., Fowler, D., Dragosits, U., Howard, D., Sutton, M., and Famulari, D.: Detecting the signal of atmospheric $\mathrm{N}$ deposition in recent nationalscale vegetation change across Britain, Water Air Soil Poll., 4, 269-278, https://doi.org/10.1007/s11267-005-3037-5, 2005a.

Smart, S., Bunce, R., Marrs, R., LeDuc, M., Firbank, L., Maskell, L., Scott, W., Thompson, K., and Walker, K.: Large-scale changes in the abundance of common higher plant species across Britain between 1978, 1990 and 1998 as a consequence of human activity: tests of hypothesised changes in trait representation, Biol. Conserv., 124, 355-371, https://doi.org/10.1016/j.biocon.2004.12.013, 2005 b.
Smart, S., Maskell, L., Dunbar, M., Emmett, B., Marks, S., Norton, L., Rose, P., and Simpson, I.: An Integrated Assessment of Countryside Survey data to investigate Ecosystem Services in Great Britain. Countryside Survey Technical Report No. 10/07, NERC Centre for Ecology and Hydrology, Lancaster, 2010a.

Smart, S., Henrys, P. A., Scott, W. A., Hall, J. R., Evans, C. D., Crowe, A., Rowe, E. C., Dragosits, U., Page, T., Whyatt, J. D., Sowerby, A., and Clark, J. M.: Impacts of pollution and climate change on ombrotrophic Sphagnum species in the UK: analysis of uncertainties in two empirical niche models, Clim. Res., 45, 163-177, https://doi.org/10.3354/cr00969 2010b.

Smart, S., Scott, W. A., Whitaker, J., Hill, M. O., Roy, D. B., Critchley, C. N., Marina, L., Evans, C., Emmett, B. A., Rowe, E. C., Crowe, A., and Marrs, R. H.: Empirical realised niche models for British higher and lower plants - development and preliminary testing, J. Veg. Sci., 21, 643-656, https://doi.org/10.1111/j.16541103.2010.01173.x, 2010c.

Smart, S. M. and DART Computing: Modular Analysis of Vegetation Information System (MAVIS), Centre for Ecology and Hydrology, http://www.ceh.ac.uk/services/ modular-analysis-vegetation-information-system-mavis, last access: 16 November, 2017.

Smart, S. M., Firbank, L. G., Bunce, R. G. H., and Watkins, J. W.: Quantifying changes in abundance of food plants for butterfly larvae and farmland birds, J. Appl. Ecol., 37, 398-414, https://doi.org/10.1046/j.1365-2664.2000.00508.x, 2000.

Smart, S. M., Bunce, R. G. H., Firbank, L. G., and Coward, P.: Do field boundaries act as refugia for grassland plant species diversity in intensively managed agricultural landscapes in Britain?, Agr. Ecosyst. Environ., 91, 73-87, https://doi.org/10.1016/S0167-8809(01)00259-6, 2002.

Smart, S. M., Marrs, R. H., Le Duc, M. G., Thompson, K., Bunce, R. G., Firbank, L. G., and Rossall, M. J.: Spatial relationships between intensive land cover and residual plant species diversity in temperate farmed landscapes, J. Appl. Ecol., 43, 1128-1137, https://doi.org/10.1111/j.1365-2664.2006.01231.x, 2006a.

Smart, S. M., Thompson, K., Marrs, R. H., Le Duc, M. G., Maskell, L. C., and Firbank, L. G.: Biotic homogenization and changes in species diversity across humanmodified ecosystems, P. Roy. Soc. B, 273, 2659-2665, https://doi.org/10.1098/rspb.2006.3630, 2006b.

Smart, S. M., Scott, A., and Clarke, R.: Quality Assurance Report - Analysis of plant species recording bias in Countryside Survey terrestrial vegetation plots - summary report, Centre for Ecology \& Hydrology, Lancaster, 2008.

Smart, S. M., Allen, D., Murphy, J., Carey, P. D., Emmett, B. A., Reynolds, B., Simpson, I. C., Evans, R. A., Skates, J., Scott, W. A., Maskell, L. C., Norton, L. R., Rossall, M. J., and Wood, C. Countryside Survey: Wales Results from 2007, NERC/Centre for Ecology \& Hydrology, Wallingford, UK, 94, 2009.

Smart, S. M., Henrys, P. A., Purse, B. V., Murphy, J. M., Bailey, M. J., and Marrs, R. H.: Clarity or confusion?: problems in attributing large-scale ecological changes to anthropogenic drivers, Ecol. Indic., 20, 51-56, https://doi.org/10.1016/j.ecolind.2012.01.022, 2012.

Smart, S. M., Glanville, H. C., Blanes, M. d. C., Mercado, L. M., Emmett, B. A., Jones, D. L., Cosby, B. J., Marrs, R. H., Butler, A., Marshall, M. R., Reinsch, S., Herrero-Jáuregui, C., and Hodgson, J. G.: Leaf dry matter content is better at pre- 
dicting above-ground net primary production than specific leaf area, Funct. Ecol., 31, 1336-1344, https://doi.org/10.1111/13652435.12832, 2017.

Ståhl, G., Allard, A., Esseen, P.-A., Glimskär, A., Ringvall, A., Svensson, J., Sundquist, S., Christensen, P., Torell, ̊.. G., and Högström, M.: National Inventory of Landscapes in Sweden (NILS)—scope, design, and experiences from establishing a multiscale biodiversity monitoring system, Environ. Monit. Assess., 173, 579-595, 2011.

Stevens, C., Maskell, L., Smart, S., Caporn, S., Dise, N., and Gowing, D.: Identifying indicators of atmospheric nitrogen deposition impacts in acid grasslands, Biol. Conserv., 142, 2069-2075, https://doi.org/10.1016/j.biocon.2009.04.002, 2009.

Stevens, C. J., Payne, R. J., Kimberley, A., and Smart, S. M.: How will the semi-natural vegetation of the UK have changed by 2030 given likely changes in nitrogen deposition?, Environ. Pollut., 208, 879-889, https://doi.org/10.1016/j.envpol.2015.09.013, 2016.

van den Berg, L. J., Jones, L., Sheppard, L. J., Smart, S. M., Bobbink, R., Dise, N. B., and Ashmore, M. R.: Evidence for differential effects of reduced and oxidised nitrogen deposition on vegetation independent of nitrogen load, Environ. Pollut., 208, 890-897, https://doi.org/10.1016/j.envpol.2015.09.017, 2016.
Villoslada, M., Bunce, R. G. H., Sepp, K., Jongman, R. H. G., Metzger, M. J., Kull, T., Raet, J., Kuusemets, V., Kull, A., and Leito, A.: A framework for habitat monitoring and climate change modelling: construction and validation of the Environmental Stratification of Estonia, Reg. Environ. Change, 17, 1-15, https://doi.org/10.1007/s10113-016-1002-7, 2016.

Watson, R., Albon, S., Aspinall, R., Austen, M., Bardgett, B., Bateman, I., Berry, P., Bird, W., Bradbury, R., and Brown, C.: UK National Ecosystem Assessment: Technical Report, United Nations Environment Programme World Conservation Monitoring Centre, Cambridge, 2011.

Wood, C. M. and Bunce, R. G. H.: Survey of the terrestrial habitats and vegetation of Shetland, 1974 - a framework for longterm ecological monitoring, Earth Syst. Sci. Data, 8, 89-103, https://doi.org/10.5194/essd-8-89-2016, 2016.

Wood, C. M., Howard, D. C., Henrys, P. A., Bunce, R. G. H., and Smart, S. M.: Countryside Survey: measuring habitat change over 30 years: 1978 data rescue - final report, Centre for Ecology \& Hydrology, Lancaster, 2012.

Wood, C. M., Smart, S. M., and Bunce, R. G. H.: Woodland Survey of Great Britain 1971-2001, Earth Syst. Sci. Data, 7, 203-214, https://doi.org/10.5194/essd-7-203-2015, 2015. 